\title{
Participation in Conducting The Visual Inspection of Acetic Acid as an Early Detection Effort Towards The Servical Cancer Reviewed from Information Access and Knowledge
}

\author{
Winarni ${ }^{1 *}$, Rina Sri Widayati ${ }^{2}$, Sri Handayani ${ }^{3}$ \\ ${ }^{1 *}$ Universitas'Aisyiyah Surakarta \\ ${ }^{2}$ Universitas'Aisyiyah Surakarta \\ ${ }^{3}$ Universitas'Aisyiyah Surakarta \\ *E-mail: bunda.aya06@gmail.com \\ https://doi.org/10.30787/gaster.v19i1.665
}

\section{ARTICLE INFO}

Keywords: $\quad$ Knowledge;

Information Access; IVA

Participation

\section{ABSTRACT}

Background: the problem of the reproduction health is appeared because of the lack knowledge for women about reproduction health such as hygiene problem which can lead to various diseases of reproductive organs, one of those is cervical cancer. This cancer places at the second rank after breast cancer as the most common cancer suffered by Indonesian women. It is noted that there are more than 270.000 women died because of the servical cancer and it is estimated about 40.000 new cases of its cancer in each year. Aim: this study is aimed to analyze the knowledge and information access with mothers' participation in conducting the visual inspection of acetic acid. Method: the type of this study is an analytic observational research. The population is the couple of mothers in childbearing age of a study and communication forum for moeslem women in Pucangan. The sampling technique applies the saturated sample that fulfilling the inclusion criteria, totally 76 respondents. Data Analysis uses $X^{2}$ for bivariate and logistics regression for multivariate. Result: there is a correlation of information access with the mothers' participation in conducting visual inspection of acetic acid and there is a correlation of knowledge with the mothers' participation in conducting visual inspection of acetic acid. Conclusion: knowledge and information access are including variables that can influence participation in the IVA test checkup are about $65.5 \%$ and the remaining are about $31.5 \%$ influenced by other factors outside the research model. 


\section{INTRODUCTION}

The reproduction health is a most complicated problem for women. Many problems of health production are appeared because of the lack of knowledge by them about health production such as hygiene problem that can lead to various disease of reproductive organs, one of those case is the servical cancer (Arum and Prabandari, 2012; Gaffikin. et all, 2017).

The servical cancer has placed at second rank after breast cancer as the most common cancer suffered by Indonesian Women. It is noted that there are more than 270.000 women died because of the servical cancer and it is estimated about 40.000 new cases of its cancer in each year (Mirayasih, 2013; Rasjidi, 2016). Incidence cancer of Central Java in 2018 reached an estimate 68.638 people, While data ot the Semarang city in 2018 reached 406 cervical cancer case (Dinas Kesehatan Prop Jateng, 2018). Wile 39 cases in Sukoharjo and 9 cases of cervical canser in Kartasura (Dinas Kesehatan Kab Sukoharjo, 2018).

The number of women in fertile age who have conducted the early detection of cervical cancer and breast cancer in Central Java in 2018 are reported about 94,509 women in fertile age (1.92\%) of women aged 30-50 years. Based on the data of women in fertile age through the IVA test, it is found that 4,493 IVA are positive (4.75\%), it means that the score is higher than $3 \%$ as determined by the Ministry of Health (Dinas Kesehatan Prop Jateng, 2018). In Sukoharjo, it shows that $890(24,22 \%)$ of 3675 women in fertile age who conducting IV A test are considered as positive, while in Kartosuro 67 (20.94\%) of 320 women in fertile age are also positive (Dinas Kesehatan Kab Sukoharjo, 2018).

The cause of the high incidence of the servical cancer, one of which is caused by the lack of women knowledge about the servical cancer and the low of their awareness to follow the early detection. The good knowledge of the servical cancer can motivate them to do prevention as early as possible by conducting early detection such as visual inspection of acetic acid (Mirayasih, 2013; Arum and Prabandari, 2015).

IVA is one of early detection efforts and also considered as an official government program in case of decreasing the servical cancer cases. The government has decided the target at minimum range $80 \%$ of women aged in 30-50 years to conduct early detection on each 5 years (Mirayasih, 2013). The IVA test is also applied by several Health Care Center of Sukoharjo that purposed to execute early detection for the servical cancer in order to reach all society elements. 
The aim of this study is to know the correlation of knowledge and information access towards the mothers' participation in conducting the visual inspection of acetic acid. Based on those phenomenon, the researchers are interested to conduct a study entitled 'Mothers' Participation in Conducting the Visual Inspection of Acetic Acid Reviewed from Information Access and Knowledge in A Study and Communication Forum for Moeslem Women in Kartosuro Sukoharjo".

\section{METHODS AND MATERIALS}

This study applies an analytic observational method that purposed to reveal the correlative correlation among variables designed by the cross sectional time approach. Population used in this study is the couple of mothers in childbearing age of a study and communication forum for moeslem women in Kartosuro, Sukoharjo. The sample uses the total of population that fulfills the inclusion and exclusion criteria. Inclusion criteria in this study: Women who are married and have had sexual relations with the age range of 3050 years and are willing to be respondents. Exclusion criteria in this study: Women who have done early detection of Cervical Cancer in addition to IVA tests and women who positively have cervical cancer.
In this study, there are three variables that analyzed namely knowledge, information access (independent variables), and participation of early detection of the servical cancer with IVA method (dependent variable).

The research instrument used is questionnaire. The question applied is closed ended question in form of dichotommous choice. The study consists of one kind of data namely primary data which it collected from respondents through questionnaire directly. Before answering it, respondents are early given several directions about the way to fill its questionnaire and then they are provided several informed content that followed by submitting their questionnaire. The technique of processing data is including several steps namely editing, coding and tabulating. Data analysis is conducted by using $\mathrm{X}$ test. The test criteria is that $\mathrm{H}_{\mathrm{o}}$ is accepted if $p$ value $\geq 0.05$. The logistics regression is applied to know the correlation among independent variable and dependent variable simultaneously.

\section{RESULTS AND DISCUSSION}

There are two main factors that shape the personal behavior, namely stimulus which is that a factor comes from outside the person (external factor) and the response which is that a factor from within the concerned 
person (internal factor). In this discussion, it which concerned to mothers' participation in will be discussed about the external factors early detection using IVA test.

Table1. Frequency Distribution of Respondent Characteristics, Information Media Access and Participation of IVA Test.

\begin{tabular}{llcc}
\hline Characteristics & \multicolumn{1}{c}{ Criteria } & n & \% \\
\hline Information Access & Just one media & 36 & $47,4 \%$ \\
& More than one media & 40 & $52,6 \%$ \\
Knowledge & & 76 & $100 \%$ \\
& Less & 22 & $28,9 \%$ \\
& Good & 54 & $71,1 \%$ \\
Education & & 76 & $100 \%$ \\
& & & \\
& & 53 & $69,7 \%$ \\
Participation of IVA Test & Yower educational level & 23 & $30,3 \%$ \\
& & 76 & $100 \%$ \\
& Yes & & \\
& No & 54 & $71,1 \%$ \\
& & 22 & $28,9 \%$ \\
& & 76 & $100 \%$ \\
\hline
\end{tabular}

(Source: primary data processed in 2019)

1. Correlation of Mothers' Information Access with Participation in the IVA Test Checkup

Table 2. Correlation of Mothers' Information Access with Participation in the IVA Test Checkup

\begin{tabular}{|c|c|c|c|c|c|c|c|c|}
\hline \multirow{3}{*}{$\begin{array}{l}\text { Information } \\
\text { Access }\end{array}$} & \multicolumn{4}{|c|}{ Participation in the IVA Test } & \multirow{2}{*}{\multicolumn{2}{|c|}{ Total }} & \multirow{3}{*}{ OR } & \multirow{3}{*}{$\mathbf{p}$} \\
\hline & \multicolumn{2}{|c|}{ No } & \multicolumn{2}{|c|}{ Yes } & & & & \\
\hline & $\mathbf{F}$ & $\%$ & $\mathbf{F}$ & $\%$ & $\mathbf{F}$ & $\%$ & & \\
\hline One media & 16 & 40,0 & 24 & 60,0 & 40 & 100 & & \\
\hline $\begin{array}{l}\text { More than one } \\
\text { media }\end{array}$ & 6 & 16,7 & 30 & 83,3 & 36 & 100 & 3,33 & 0,025 \\
\hline Total & 22 & 28,9 & 54 & 71,1 & 76 & 100 & & \\
\hline
\end{tabular}

(Source: primary data processed in 2019) 
Table 1 shows $52.6 \%$, it means that the respondents always access information more one media such as from electronic media, printing media, health officers, and friends. They are who have got information about the servical cancer are more understood about the risks of servical cancer and benefit in conducting IVA test, then those cases will motivate them to conduct its test soon. This current study is in line with the result of previous study by Rohmawati (2011) which conclude that the collected health information will encourage the health behavior.

The result of Chi-Square test on the table 2 shows that there is a correlation of mothers' information access with participation in the IVA test checkup and the statistics analysis has proved it significantly $(\mathrm{p}=0,025)$. The score of Odds Ratio is about 3.33, it means that mothers who get the information access more than one media (electronic media, printing media, health officers, and friends) have the possibility 3.33 times larger than participation in the IVA test checkup compared to the mothers who get the information access from only one media (electronic media).

The current modern technology such as electronic media can influence the people knowledge about new innovation on health. As communication media, there are various kind of electronic media such as handphone, television, radio, internet, and so on having large influence towards the opinion formation and personal confidence. In spreading information, the electronic media brings messages that containing suggestion that can steer personal opinion. The result of this current study is different against the result of previous studies conducted by Artiningsih (2010) and Dewi (2014) that described that most of respondents just get the information about the servical cancer from the health officers.

2. Correlation of the Servical Cancer Knowledge with Mothers' Participation in Conducting the IVA Test

Table 3. Correlation of Mothers' Knowledge with Participation in the IVA Test Checkup

\begin{tabular}{|c|c|c|c|c|c|c|c|c|}
\hline \multirow{3}{*}{ Knowledge } & \multicolumn{4}{|c|}{ Participation of the IVA Test } & \multirow{2}{*}{\multicolumn{2}{|c|}{ Total }} & \multirow{3}{*}{ OR } & \multirow{3}{*}{$\mathrm{p}$} \\
\hline & \multicolumn{2}{|c|}{ No } & \multicolumn{2}{|c|}{ Yes } & & & & \\
\hline & $\mathrm{F}$ & $\%$ & $\mathrm{~F}$ & $\%$ & $\mathrm{~F}$ & $\%$ & & \\
\hline Less & 13 & 59,1 & 9 & 40,9 & 22 & 100 & 7,22 & $<0,001$ \\
\hline
\end{tabular}




\begin{tabular}{|c|c|c|c|c|c|c|c|c|}
\hline \multirow{3}{*}{ Knowledge } & \multicolumn{4}{|c|}{ Participation of the IVA Test } & \multirow{2}{*}{\multicolumn{2}{|c|}{ Total }} & \multirow{3}{*}{ OR } & \multirow{3}{*}{$\mathrm{p}$} \\
\hline & \multicolumn{2}{|c|}{ No } & \multicolumn{2}{|c|}{ Yes } & & & & \\
\hline & $\mathrm{F}$ & $\%$ & $\mathrm{~F}$ & $\%$ & $\mathrm{~F}$ & $\%$ & & \\
\hline Good & 9 & 16,7 & 45 & 83,3 & 54 & 100 & & \\
\hline Total & 22 & 28,9 & 54 & 71,1 & 76 & 100 & & \\
\hline
\end{tabular}

(Source: primary data processed in 2018)

Table 1 shows that most of respondents have good knowledge (71.1\%). It means that most of respondents who have good knowledge are citizen, it is reasonable that they will be easier to access information about the servical cancer. In general, knowledge is influenced by several factors namely education, job, age, and information (Mubarak, 2011; Rohmawati, 2016; Dewi, 2014). Based on the result of the previous studies, it has proved that the respondent educational level which is most in senior high school and university will be easier in accepting information indirectly, so their knowledge can be upgraded well.

Besides, knowledge is also influenced by age which mothers in pre menopause feel more susceptible to disease so they will be motivated to conduct the preventive measure. This case is accordance with the theory of Mubarak which describes that factors that can influence the personal knowledge are education, age, and information (Mubarak, 2011; Rosita, 2012).

Most of human knowledge are collected through sight and hearing. Knowledge is a crucial domain that leads the personal behavior. The behavior based on knowledge will last rather than not based it anymore (Notoadmodjo, 2015).

Table 3 shows that the respondents who have good knowledge will participate in the IVA test checkup. This case is accordance with Green's theory which describes that knowledge is one of the personal behavior formation factors. Someone who has higher knowledge will be easier to change his act better than someone in the lower knowledge (Green L, 1980, in Notoatmodjo, 2015).

4. Analysis of Internal Determinants and Information Access with Mothers' Participation in Conducting the Visual Inspection of Acetic Acid 
Table 4. The Result of Processing Data Using Logistics Regression

\begin{tabular}{lcccc}
\hline Variable & \multirow{2}{*}{ OR } & \multicolumn{2}{c}{ CI 95\% } & p \\
\cline { 3 - 4 } & & Lower limit & Upper limit & Wald Test \\
\hline Information Access & 9,26 & 1,29 & 66,65 & 0,027 \\
Mothers' Knowledge & 17,14 & 2,87 & 102,26 & 0,002 \\
N observation & 76 & & & \\
-2 log likelihood & 41,86 & & & \\
Nagelkerke R ${ }^{2}$ & $68,5 \%$ & & & \\
\hline
\end{tabular}

(Source: primary data processed in 2019)

The score of Odd Ratio in mothers' information access is about 9.26. It means that mothers who get the information access more than one media (Electrical media, printing media, health officers, and friends) have the possibility 9.26 times larger than the participation in the IVA test checkup compared to they who have the information access from just one media (electronic media). The result of the wald test shows that there is a correlation between mothers' information access with the participation in the IVA test checkup and the statistics analysis has proved it significantly $(\mathrm{OR}=9,26$; $\mathrm{CI}=95 \% ; 1,29$ hingga 66,$65 ; \mathrm{p}=0,027)$.

The score of Odd Ratio in mothers' knowledge variable is about 17.14. It means that mothers' who own good knowledge (score $>$ mean) have the possibility 17.14 times larger than the participation in the IVA test checkup compared to mothers who have less knowledge (score $<$ mean). The result of wald test shows that there is a correlation between mothers' knowledge with the participation in the IVA test checkup and the statistics analysis has proved it significantly $(\mathrm{OR}=17,14 ; \mathrm{CI}=95 \% ; 2,87$ hingga 102,26; $\mathrm{p}=0,002$ ).

The score of NegelkerkeR ${ }^{2}$ about $68,5 \%$ means that all independent variables (information access and mothers' knowledge) are able to influence the participation in the IVA test checkup about $68.5 \%$ and the remaining is about $31.5 \%$ influenced by other factors ouside the research model.

\section{CONCLUSION AND RECOMMENDATION}

Based on the result of data analysis and discussion above, it can be assumed that: 
There is a correlation of information access with the mothers' participation in conducting the visual inspection of acetic acid, the score of Odd Ratio 9.26 means that mothers with information access more than one media have the possibility about 9.26 times larger compared to the participation of the IVA test checkup.

There is correlation of knowledge with the mothers' participation in conducting the visual inspection of acetic acid, the score of Odds Ratio 17.14 means that mothers with good knowledge (score $>$ mean) have the possibility about 17.14 times larger compared to the participation of the IVA test checkup. The mothers' knowledge and information access are able to influence the participation in the IVA test checkup are $68.5 \%$ and its remaining are about $31.5 \%$ influenced by the other factors outside the research model.

Based on the result of this study, it can be declared several recommendations as following:

For the decision makers of the Public Health Office in Sukoharjo, they are expected to be more active in providing the development for their health officers in order to be active in promoting IVA test checkup as an early detection for the servical cancer. Then, they should put it in the regional development planning on health field, and providing the facilities and infrastructures for its early detection activities. For health organization, it can be suggestion to health officers to increase the counseling about importance of early detection towards the cervical cancer on the active WUS in sexuality, and availability of facilities and infrastructures in health service especially for early detection of the servical cancer.

\section{REFERENCES}

Artiningsih, N. 2010. Hubungan Antara Tingkat Pengetahuan dan Sikap Wanita Usia Subur dengan Pemeriksaan Inspeksi Visual Asam Asetat Dalam Rangka Deteksi Dini Kanker Leher Rahimdi Wilayah Puskesmas Blooto, Mojokerto. (Tesis). Surakarta. Universitas Sebelas Maret Surakarta.

Arum, R dan Prabandari, F. 2012. Beberapa Faktor yang Mempengaruhi Minat Wanita Usia Subur Dalam Melakukan Pemeriksaan Iva. Jurnal Ilmiah Kebidanan, Vol.3 No.1 Edisi Juni 2012

Dewi, L. 2014. Faktor-faktor yang Berhubungan dengan Perilaku Wanita Usia Subur dalam Deteksi Dini Kanker Leher Rahimdi Puskesmas Tanjung 
Hulu Pontianak. (Skripsi). Pontianak. Universitas Tanjungpura, Pontianak.

Dinas Kesehatan. 2018. Profil Kesehatan

Provinsi Jawa Tengah 2018. Semarang:

Dinkes Jateng.

Dinas Kesehatan. 2018. Profil Kesehatan Kabupaten Sukoharjo 2018. Sukoharjo:

Dinkes Sukoharjo.

Gaffikin, L., McGrath, J., Arbyn,. Blumenthal, P. 2017. Visual Inspection with Asetic Acid as a Cervical Cancer Test: Accuracy Validated Using Latent Class Analysis. BMC J Medical Research, USA.

Mirayasih, D. 2013. Hubungan Antara Tingkat Pengetahuan Tentang Kanker Leher Rahimdan Keikutsertaan Melakukan Pemeriksaan Inspeksi Visual Asam Asetat di Puskesmas Alianyang Pontianak. (Skripsi). Pontianak. Universitas Tanjung Pura Pontianak.
Mubarak, I. 2011. Promosi Kesehatan untuk Kebidanan, Salemba Medika, Jakarta.

Notoatmodjo, S. 2015. Promosi Kesehatan dan Perilaku Kesehatan, Rineka Cipta, Jakarta.

Rasjidi, I. 2016. Epidemiologi Kanker Pada Wanita, CV Sagung Seto, Jakarta.

Rohmawati, I. 2016. Faktor-faktor yang Berhubungan dengan Perilaku Wanita Usia Subur dalam Deteksi Dini Kanker Serviks dengan Metode IVA di Wilayah Kerja Puskesmas Ngawen I Kabupaten Gunung Kidul. (Tesis). Depok. Universitas Indonesia.

Rosita. 2012. Hubungan Pengetahuan Ibu Tentang Kanker Leher Rahim dengan Perilaku Deteksi Dini Kanker Leher Rahim pada Ibu di Desa Ngebel, Ponorogo. (Skripsi). Surakarta. Stikes 'Aisyiyah, Surakarta. 